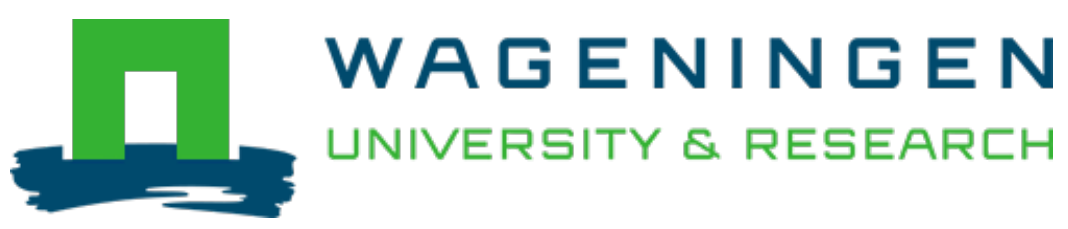

\title{
Credit Constraints and Rural Households' Entrepreneurial Performance in China
}

Emerging Markets Finance and Trade

Weng, Chen; Wang, Hui; Heerink, Nico; Berg, Marrit

https://doi.org/10.1080/1540496X.2020.1788538

This publication is made publicly available in the institutional repository of Wageningen University and Research, under the terms of article $25 \mathrm{fa}$ of the Dutch Copyright Act, also known as the Amendment Taverne. This has been done with explicit consent by the author.

Article $25 \mathrm{fa}$ states that the author of a short scientific work funded either wholly or partially by Dutch public funds is entitled to make that work publicly available for no consideration following a reasonable period of time after the work was first published, provided that clear reference is made to the source of the first publication of the work.

This publication is distributed under The Association of Universities in the Netherlands (VSNU) 'Article $25 \mathrm{fa}$ implementation' project. In this project research outputs of researchers employed by Dutch Universities that comply with the legal requirements of Article $25 \mathrm{fa}$ of the Dutch Copyright Act are distributed online and free of cost or other barriers in institutional repositories. Research outputs are distributed six months after their first online publication in the original published version and with proper attribution to the source of the original publication.

You are permitted to download and use the publication for personal purposes. All rights remain with the author(s) and / or copyright owner(s) of this work. Any use of the publication or parts of it other than authorised under article $25 \mathrm{fa}$ of the Dutch Copyright act is prohibited. Wageningen University \& Research and the author(s) of this publication shall not be held responsible or liable for any damages resulting from your (re)use of this publication.

For questions regarding the public availability of this publication please contact openscience.library@wur.nl 


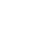

\section{Credit Constraints and Rural Households' Entrepreneurial Performance in China}

\section{Chen Weng, Hui Wang, Nico Heerink \& Marrit van den Berg}

To cite this article: Chen Weng, Hui Wang, Nico Heerink \& Marrit van den Berg (2022) Credit Constraints and Rural Households' Entrepreneurial Performance in China, Emerging Markets Finance and Trade, 58:2, 570-583, DOI: 10.1080/1540496X.2020.1788538

To link to this article: https://doi.org/10.1080/1540496X.2020.1788538

\section{+ View supplementary material $\square$}

2020.

Submit your article to this journal $₫$

Џ Article views: 136

Q View related articles $\sqsubset$

View Crossmark data〔 


\title{
Credit Constraints and Rural Households' Entrepreneurial Performance in China
}

\author{
Chen Weng ${ }^{a}$, Hui Wang ${ }^{a}$, Nico Heerink ${ }^{b}$, and Marrit van den Berg ${ }^{b}$ \\ aSchool of Finance, Nanjing University of Finance and Economics, Nanjing, Jiangsu, China; ${ }^{b}$ Development \\ Economics Group, Wageningen University, Wageningen, The Netherlands
}

\begin{abstract}
Based on data from the China Household Finance Survey, this article investigates the relationship between formal sector credit constraints and rural households' entrepreneurial performance. Using an endogenous switching regression model, we find that credit-constrained entrepreneurial households' profits are significantly and positively affected by credit access, which is measured by total formal and informal production loans owed. With an extra RMB 10,000 in credit, constrained entrepreneurial households' average profits would be raised from RMB 10,604 to RMB 10,732 (i.e. by 1.2\%). Entrepreneurial profits of households that are not credit-constrained do not depend on loan sizes. Based on our findings, we stress the importance of the development of new-type rural financial institutions, proper compensations for expropriated land, and stimulating savings and investments in different types of assets for improving the performance of rural entrepreneurs.
\end{abstract}

\section{KEYWORDS}

Credit constraints; entrepreneurial performance; rural households; China

JEL

Q14; R29

\section{Introduction}

Entrepreneurs are an important source to foster innovation and economic growth. The central government of China proposed "mass entrepreneurship and innovation" and implemented a series of strategies to encourage entrepreneurship (Zhang, Zhuge, and Freeman 2020a). Among which, alleviating the credit constraints of entrepreneurs attracts much attention. Entrepreneurship is challenging in a rural economy with an imperfect credit market. Based on China Household Finance Survey in 2011, we find that almost 60\% of rural entrepreneurial households who are in need of credit are not able to obtain bank loans. This low credit accessibility for rural entrepreneurs enables us to further explore the reason behind it. It shows that a lack of qualified collaterals and guarantors are two dominating reasons for rejections on loan applications. Somewhat surprisingly, an even larger share of constrained rural entrepreneurial households, which is much more than three times of that rejection cases, results from the fact that these households have never applied for bank loans though needed.

CONTACT Chen Weng dorisweng90@hotmail.com $@$ School of Finance, Nanjing University of Finance and Economics, Nanjing, Jiangsu, China

(- Supplemental data for this article can be accessed on the publisher's website. 
Binding constraints might restrict entrepreneurs to operate their business under sub-optimal input of capital, thus lowing their performance. Therefore, we come up with the following question: Whether and how credit constraints from formal sectors affect rural entrepreneurial households' performance in China?

Existing studies have examined the relationship between credit constraints and entrepreneurial performance in developed countries (e.g. Burke, FitzRoy, and Nolan 2000; Evans and Jovanovic 1989; Hvide and Møen 2007). The logic behind is that: If entrepreneurs cannot borrow to attain an optimal level of capital inputs, then those entrepreneurs with more personal wealth will perform better than those with less wealth. These studies use personal wealth (or personal wealth shocks such as receiving inheritances) as the measurement for credit constraints. However, the potential problem lying in these studies is that the possibility of obtaining external finance remains unconsidered (Van Praag, De Wit, and Bosma 2005). In the context of China, some studies take advantage of China Household Finance Survey (CHFS) data, which collected a national-representative sample at the household level. They examined the relationship between credit constraints and the new entry of entrepreneurship, and found that credit constraints significantly decrease the possibility of households to become entrepreneurs (Cai et al. 2018; Ma, Wu, and Gan 2019). However, credit constraints do not exist solely during the start-up stage. Entrepreneurs are still faced with severe financing difficulties once their business started (Zhang et al. 2020b). Yet less light has been shed on the effect of credit constraints on entrepreneurial performance.

This article aims to examine how formal sector credit constraints would affect entrepreneurial performance in rural China. It complements the literature on the following aspects: Firstly, instead of using personal wealth as a measurement for credit constraints in previous studies, we identify whether entrepreneurial households are suffering from external credit constraints, i.e., the accessibility of credit from formal financial institutions, thanks to the abundant information on households' access to formal credit provided by the CHFS dataset. Secondly, existing studies on the relationship between credit constraints and entrepreneurial performance mostly concern with evidences in developed countries. However, few evidence can be found in developing countries like China. Pioneered by studies that focus on the effect of credit constraints on households' choice of starting a business in China by using CHFS dataset (Cai et al. 2018; Ma, Wu, and Gan 2019), we extend their work by focusing on the effect of credit constraints on entrepreneurial households' performance (i.e. profits) once the entrepreneurs start their business successfully. Finally, different from previous studies that simply use ordinary least square or instrumental variable regression method to examine the relationship between credit constraints and entrepreneurship, we employ an endogenous switching regression model to test the theory of financial market efficiency in rural economy. Since the rural credit market is imperfect in China, 
unconstrained entrepreneurs will have marginal returns to capital that equal the market interest rate, while constrained entrepreneurs will have higher and differing marginal returns. By using the endogenous switching regression model, we can explicitly identify the difference in entrepreneurial performance between constrained and unconstrained entrepreneurs.

The remainder of the article is organized as follows: Section 2 describes the data and presents descriptive statistics. Section 3 presents the empirical approach used for estimating the effect of credit constraints on entrepreneurial performance. Section 4 reports and discusses the empirical results, and section 5 concludes with discussing the policy implications of our findings.

\section{Data and Descriptive Statistics}

\subsection{Data}

Our analysis is based on the first-round data of the China Household Finance Survey (CHFS) carried out in 2011 by the Survey and Research Center for China Household Finance, Southwestern University of Finance and Economics, Chengdu, China. The survey includes information on demographic characteristics, family assets, household participation in credit markets, agricultural production, and business management for a total sample of 8,438 households in 80 counties from all provinces in mainland China except Tibet, Xinjiang, and Inner Mongolia. ${ }^{1}$ Among all sampled households, 4,405 households report having rural registered permanent residence. We identify these households as rural households.

Referring to the definition of entrepreneurs by Quadrini (2000), we consider a household as an entrepreneur if it reports that at least one household member owns a business or works in agriculture but is not employed by others. According to this definition, there are 3,184 rural entrepreneurs in the sample. By excluding those with missing or incorrect information on major relevant variables, our total sample size is reduced to 3,171 entrepreneurs.

With regard to credit constraints, we mainly focus on credit constraints in formal credit markets as rural households in China are often excluded from formal credit due to a lack of qualified collaterals (Li et al. 2013). We use the direct elicitation method to identify household credit constraint status (Figure S1). For the purpose of this study, we mainly focus on loan applications with the purpose of agricultural production or business activities. Referring to the definition of unconstrained, quantity constrained, transaction cost constrained, and risk constrained in Boucher, Guirkinger, and Trivelli (2009), we divide our sample of entrepreneurial households into similar categories according to household responses to survey questions. Firstly, we distinguish loan applicants from non-applicants by asking whether they had loans in the 
survey year. Those who did not have loans in the survey year were asked for the reasons why they did not apply for loans. Entrepreneurial households who reported they already had bank loans, had no need for bank loans, had loans but paid them off were classified as unconstrained. Constrained entrepreneurial households fall into three categories: (i) quantity constrained households who either reported that their loan application was rejected, or that they did not apply because they lacked collateral or that they feared being rejected ${ }^{2}$; (ii) transaction cost-constrained households who reported either that they lack knowledge on how to apply for a bank loan, that they considered the loan application procedure as too complicated, or that they lack guarantors; (iii) risk constrained households who reported a fear of being unable to pay back the loan.

\subsection{Descriptive Statistics}

Table S1 shows that $72 \%$ of the interviewed rural households are engaged in entrepreneurial activities. Among those entrepreneurial households, $79.6 \%$ is engaged only in agricultural activities. This share is lower in eastern China $(68.7 \%)$ than in the other parts of China. It illustrates that rural households in eastern China have more opportunities to become a wage worker and earn a salary that is often higher than that of self-employment. Table S2 shows that $16.5 \%$ of the interviewed entrepreneurial households are credit-constrained. Out of the three types of credit constraints distinguished in Figure S1, quantity constraints are mentioned most frequently (11.4\% on average). The share of entrepreneurial households facing quantity constraints declines significantly with wealth level, from $14.8 \%$ in the lowest wealth quartile to $7.7 \%$ in the wealthiest quartile, while the shares of households being transaction cost constrained and risk constrained do not change significantly between the different wealth levels. Table S3 shows that the sub-group of creditconstrained households has significantly lower revenues and net profits than the sub-group that is not credit-constrained. It suggests that credit constraints dampen the performance of entrepreneurial households, and that constrained, as well as unconstrained households in the higher wealth quartiles perform better than those in lower wealth quartiles.

\section{Methodology}

We examine the effect of credit constraints on entrepreneurial performance based on the principle of diminishing marginal returns to capital: entrepreneurs with less capital have higher profits per unit of capital than those with more capital (De Mel, McKenzie, and Woodruff 2008). The theoretical reasoning behind this is that with well-functioning credit markets, the marginal returns to capital will be independent of the entrepreneur's characteristics 
and thus the same for all entrepreneurs. In contrast, if credit markets are imperfect, the marginal returns to capital will differ between entrepreneurs; while unconstrained entrepreneurs will still operate at the profit-maximizing level through self-finance or borrowing and have marginal returns to capital that equal the market interest rate, constrained entrepreneurs will have higher and differing marginal returns. Following this reasoning, it is not possible to estimate a single profit function for both constrained and unconstrained entrepreneurs, because unobservable characteristics like household entrepreneurial ability may affect household credit status and profitability simultaneously. We, therefore, use an endogenous switching regression model to estimate the relationship between credit constraints and entrepreneurial performance.

Let an entrepreneurial household's profit for constrained and unconstrained households be denoted by $Y_{i}^{c}$ and $Y_{i}{ }^{v}$ respectively. Following McKernan (2002), the entrepreneurial household's profit functions are as follows:

$$
y_{i}=\left\{\begin{array}{l}
y_{i}^{C}=\alpha^{C} K_{i}+\beta^{C} A_{i}+\gamma^{C} X^{i}+\delta^{C} M_{i}+\varepsilon_{i}^{C} \text { if } c_{i}=1 \\
y_{i}^{U}=\alpha^{U} K_{i}+\beta^{U} A_{i}+\gamma^{U} X^{i}+\delta^{U} M_{i}+\varepsilon_{i}^{U} \text { if } c_{i}=0
\end{array}\right.
$$

where $c_{i}$ is an indicator variable for credit constraints which is equal to 1 if the household is credit constrained and equals zero for unconstrained households. $K_{i}$ represents household credit use, which is measured by the total value of formal and informal production loans owed by the household. ${ }^{3} A_{i}$ is a vector of household productive endowments such as productive assets and land. $X_{i}$ is a vector of other household characteristics. $M_{i}$ is a vector of location characteristics.

The following equations specify the credit regime of an entrepreneurial household:

$$
\begin{gathered}
{c_{i}^{*}}^{*}=\delta X_{i}+\varphi Z_{i}+u_{i} \\
C_{i}= \begin{cases}0 & \text { if } c_{i}^{*} \leq 0 \\
0 & \text { if } c_{i}^{*} \leq 0\end{cases}
\end{gathered}
$$

$c_{i}^{*}$ is a latent variable that determines the probability of household $i$ being constrained in the formal sector. $Z_{i}$ is a vector of instruments for the selection equation (2). The instruments should only have an impact on latent variable $c_{i}{ }^{*}$, but should not impact the dependent variable $y_{i}$ directly.

Table S4 gives detailed definitions of the variables used in the profit and selection equations, and Table 1 provides their mean values and standard deviations for constrained and unconstrained households separately. We use four instruments for the selection equation: the value of nonproductive assets, the number of siblings, and dummies for housing relocation and land 


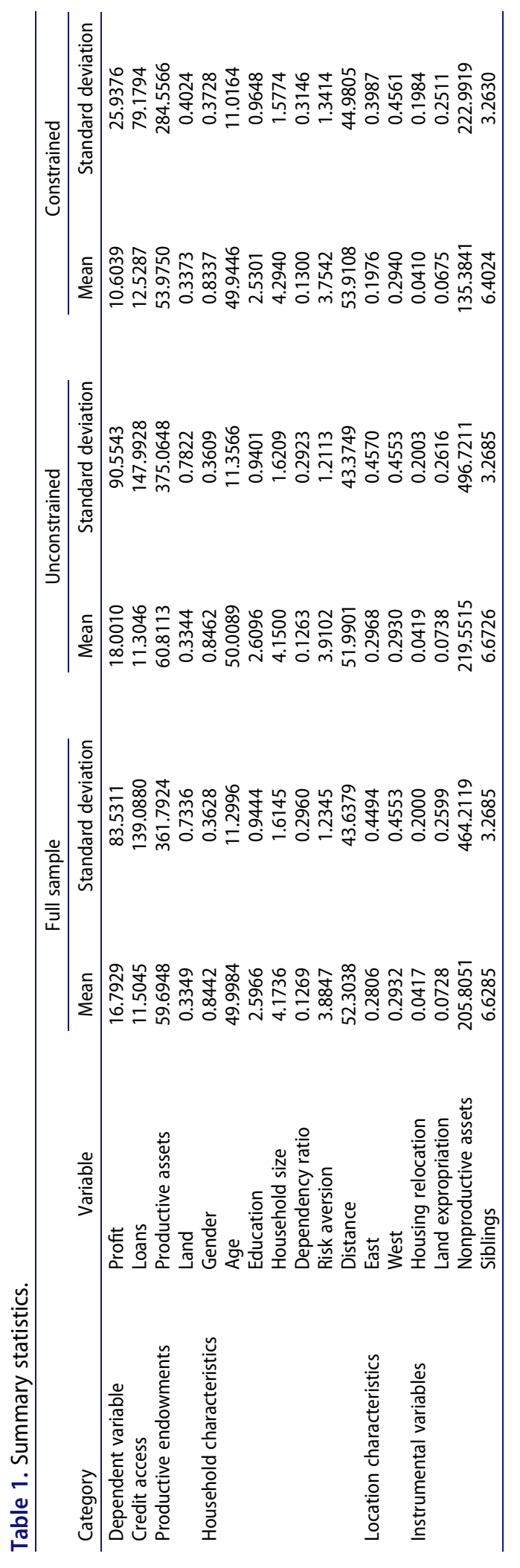


expropriation. The first instrument, nonproductive assets, is a proxy for household wealth. Wealthier households are less likely to be credit constrained as they can be self-financed or secure loans when faced with liquidity shortages. The second instrument, number of siblings, is a proxy for the households' social network. Household heads and spouses with more siblings are less likely to be credit constrained, since their social network can help gain a better access to credit. The third instrument, housing relocation, is a dummy variable indicating whether the household has ever experienced some form of housing relocation (including family workshop demolition and other forms of housing relocation). According to our survey, as much as $35 \%$ of the relocated households reported that they did not receive any compensation at all. Moreover, when asked about their satisfaction with the compensation, less than one-third (32\%) of the relocated households answered that they were satisfied or very satisfied. Therefore, we expect that housing relocation increased the likelihood of being credit constrained. The fourth instrument, land expropriation, is a dummy variable indicating whether the household has ever experienced land expropriation. In the survey, $18 \%$ of the households who had ever experienced land expropriation did not receive any compensation. As we do not know the adequacy of the compensation, the sign of the effect of land expropriation on credit constraints is indeterminate.

Some unobserved household characteristics, such as entrepreneurial ability, may affect both household credit access and entrepreneurial performance. The error terms $\varepsilon_{i}{ }^{c}, \varepsilon_{i}{ }^{v}$ in equation (1) and $u_{i}$ in equation (2) may, therefore, be correlated. To address this endogenous switching and derive consistent standard errors, we use the Full Information Maximum Likelihood (FIML) estimation method. The FIML method estimates the two equations simultaneously and generates consistent standard errors (Lokshin and Sajaia 2004). As a robustness check, we also estimate OLS regressions for constrained and unconstrained entrepreneurs separately.

\section{Results and Discussion}

\subsection{Determinants and Impacts of Credit Constraints}

The estimation results are shown in Table 2. The results for the Wald test suggest that the endogenous switching model's estimation is more efficient than the exogenous separation model. The first column of Table 2 reports the parameter estimates for the selection equation. The instruments sufficiently identify the model: three out of four instruments have a significant impact. The coefficient of land expropriation is significantly positive, indicating that households who have ever experienced land expropriation are more likely to be credit constrained. As expected, higher values of nonproductive assets and 
Table 2. Estimation results, FIML.

\begin{tabular}{|c|c|c|c|c|c|}
\hline & \multicolumn{3}{|c|}{ Endogenous switching } & \multicolumn{2}{|c|}{ Exogenous separation } \\
\hline & $\begin{array}{l}\text { Selection } \\
\text { (1) }\end{array}$ & $\begin{array}{l}\text { Unconstrained } \\
\text { (2) }\end{array}$ & $\begin{array}{c}\text { Constrained } \\
\text { (3) }\end{array}$ & $\begin{array}{l}\text { Unconstrained } \\
\text { (4) }\end{array}$ & $\begin{array}{c}\text { Constrained } \\
\text { (5) }\end{array}$ \\
\hline \multirow[t]{2}{*}{ Loans } & & 0.0001 & $0.0012^{* *}$ & -0.0003 & $0.0013^{* *}$ \\
\hline & & $(0.0004)$ & $(0.0005)$ & $(0.0006)$ & $(0.0005)$ \\
\hline \multirow[t]{2}{*}{ Productive assets } & & $0.3279^{* * *}$ & $0.2315^{* * *}$ & $0.3290^{* * *}$ & $0.2501^{* * *}$ \\
\hline & & $(0.0206)$ & $(0.0469)$ & $(0.0248)$ & $(0.0440)$ \\
\hline \multirow[t]{2}{*}{ Land } & -0.1071 & $0.2377^{* * *}$ & 0.1147 & $0.2328^{* * *}$ & 0.1891 \\
\hline & $(0.1237)$ & $(0.0778)$ & $(0.1878)$ & $(0.0586)$ & $(0.2001)$ \\
\hline \multirow[t]{2}{*}{ Gender } & 0.0273 & $0.2047^{*}$ & -0.0192 & $0.2432^{* *}$ & -0.0222 \\
\hline & $(0.0965)$ & $(0.1120)$ & $(0.1328)$ & $(0.0899)$ & $(0.1338)$ \\
\hline \multirow[t]{2}{*}{ Age } & 0.0015 & -0.0006 & 0.0017 & 0.0004 & 0.0008 \\
\hline & $(0.0024)$ & $(0.0028)$ & $(0.0070)$ & $(0.0023)$ & $(0.0069)$ \\
\hline \multirow[t]{2}{*}{ Education } & -0.0052 & $0.1156^{* * *}$ & 0.0449 & $0.1358^{* * *}$ & 0.0712 \\
\hline & $(0.0313)$ & $(0.0416)$ & $(0.0760)$ & $(0.0402)$ & $(0.0761)$ \\
\hline \multirow[t]{2}{*}{ Household size } & $0.0425^{* * *}$ & 0.0097 & 0.0138 & -0.0031 & 0.0090 \\
\hline & $(0.0159)$ & $(0.0235)$ & $(0.0378)$ & $(0.0221)$ & $(0.0339)$ \\
\hline \multirow[t]{2}{*}{ Dependency ratio } & -0.0802 & $-0.2247^{* * *}$ & -0.2540 & $-0.2498^{* * *}$ & -0.2327 \\
\hline & $(0.0921)$ & $(0.0516)$ & $(0.2140)$ & $(0.0575)$ & $(0.2016)$ \\
\hline \multirow[t]{2}{*}{ Risk aversion } & $-0.0447^{*}$ & $-0.1084^{* * *}$ & -0.0279 & $-0.0825^{* * *}$ & -0.0015 \\
\hline & $(0.0269)$ & $(0.0269)$ & $(0.0290)$ & $(0.0189)$ & $(0.0237)$ \\
\hline \multirow[t]{2}{*}{ Distance } & -0.0004 & 0.0002 & $-0.0030^{*}$ & 0.0002 & $-0.0031^{*}$ \\
\hline & $(0.0007)$ & $(0.0007)$ & $(0.0016)$ & $(0.0009)$ & $(0.0016)$ \\
\hline \multirow[t]{2}{*}{ East } & -0.2236 & -0.0683 & 0.1355 & 0.0672 & $0.2904^{*}$ \\
\hline & $(0.1483)$ & $(0.1230)$ & $(0.1394)$ & $(0.1064)$ & $(0.1563)$ \\
\hline \multirow[t]{2}{*}{ West } & -0.1534 & -0.0366 & -0.2192 & 0.0183 & -0.1437 \\
\hline & $(0.1638)$ & $(0.1693)$ & $(0.2011)$ & $(0.1742)$ & $(0.1847)$ \\
\hline \multirow[t]{2}{*}{ Housing relocation } & 0.1121 & & & & \\
\hline & $(0.0932)$ & & & & \\
\hline \multirow[t]{2}{*}{ Land expropriation } & $0.1669^{* * *}$ & & & & \\
\hline & $(0.0622)$ & & & & \\
\hline \multirow[t]{2}{*}{ Non-productive assets } & $-0.1888^{* * *}$ & & & & \\
\hline & $(0.0186)$ & & & & \\
\hline \multirow[t]{2}{*}{ Siblings } & $-0.0215^{* * *}$ & & & & \\
\hline & $(0.0063)$ & & & & \\
\hline \multirow[t]{2}{*}{ Constant } & 0.0683 & $1.6678^{* * *}$ & 0.4184 & $1.0930^{* * *}$ & $1.1706^{* * *}$ \\
\hline & $(0.1469)$ & $(0.2221)$ & $(0.3979)$ & $(0.1785)$ & $(0.3837)$ \\
\hline \multicolumn{2}{|l|}{ Sigma } & 1.3135 & 1.2100 & & \\
\hline \multicolumn{2}{|l|}{$\begin{array}{l}\text { Sigma } \\
\text { Rho }\end{array}$} & 0.9223 & 0.5378 & & \\
\hline Log pseudolikelihood & -4867.67 & & & & \\
\hline \multicolumn{6}{|c|}{ Wald test of independent equations $253.39^{* * *}$} \\
\hline \multicolumn{2}{|c|}{ Number of observations } & 2541 & & 2126 & 415 \\
\hline
\end{tabular}

Note: (1) Robust standard errors in parentheses; *** $p<0.01,{ }^{* *} p<0.05 ;{ }^{*} p<0.1$.

(2) Dependent variable is profit, which equals the natural logarithm of (one plus) profit; productive assets equal the natural logarithm of (one plus) productive assets; nonproductive assets equal the natural logarithm of (one plus) nonproductive assets.

(3) Dropping 25 observations with missing values for profits, 208 observations with profits equal to or smaller than $-1,000 \mathrm{RMB}$, and 397 observations with one or more missing values in independent variables from the initial sample (3171 rural households), finally we have a total sample size of 2,541 for model estimation.

(4) Loans and productive assets are not included in the selection function, because their values depend on whether or not the household is credit constrained.

having more siblings reduce the probability of entrepreneurial households being credit constrained.

The second and third columns of Table 2 give the estimation results for the effect of loans on unconstrained and constrained entrepreneurs, respectively, using the endogenous switching model. Columns 4 and 5 present the estimation results based on exogenous separation for the same sample. The results for the two estimation methods are very similar: Credit access, as 
measured by total formal and informal production loans owed, has a significant positive effect on the profits earned from entrepreneurial activities for constrained households; for unconstrained households, the effect of loans owed on entrepreneurial profits does not differ significantly from zero. These findings suggest that when entrepreneurs do not face credit constraints, their production decisions are independent of the total credit amount. For credit-constrained entrepreneurs, an increase of RMB 10,000 in total credit would raise their profits on average from RMB 10,604 to $\mathrm{RMB} 10,732$ (i.e. 1.2\%). Meanwhile, the profit growth rate for creditconstrained ones would increase with the rising of available total credit. Our finding is consistent with earlier similar studies by Guirkinger and Boucher (2008), Ali, Deininger, and Duponchel (2014), who also report that productivity is independent of endowments for unconstrained households, but is positively related with endowments such as credit for constrained households.

Regarding the other explanatory variables, we find that productive assets have significant positive effects on profits for both unconstrained and constrained entrepreneurs. The estimated coefficient is larger for unconstrained entrepreneurs $(0.3279$ versus 0.2315$)$, suggesting that credit constraints limit the returns to productive assets. Most other control variables reveal the expected effect, but surprisingly mostly for unconstrained entrepreneurs. For constrained entrepreneurs, the effects of loans and productive assets appear to dominate profits. The only variable that also has a significant effect on the profits of these entrepreneurs is the distance to the nearest city (county) center: Remoteness decreases profits. For unconstrained entrepreneurs, land size shows a positive and significant effect on profits in line with the effect of other productive assets. In addition, we find that male entrepreneurs and entrepreneurs with higher education levels gain more profits, while profits decrease with higher dependency ratios and risk aversion levels. The above evidence suggests that the effect of credit constraints on profits mainly operates through lowering production outcomes from sub-optimal allocation of factors of production such as productive assets.

\subsection{Robustness Check}

The estimated results may be sensitive to different definitions or mathematical forms of key variables. For example, an alternative definition of credit constraints or entrepreneurial households may cause differentiate correlations between credit access and entrepreneurial performance for constrained and unconstrained rural households. To check the robustness of the results, we estimated the other four specifications in this section. The estimated results of 
robustness checks are shown in Table S5. Our main findings remain robust to these checks.

\subsubsection{Estimation with a Broader Definition of Credit Constraints}

One concern is that estimated results may be sensitive to a different definition of credit constraints, because we consider entrepreneurial households as credit constrained only based on the purpose of production in the previous analysis, while households are also asked in the survey whether they are faced with credit constraints when applying formal loans for the purpose of housing and vehicles. To mitigate this concern, we apply a broader definition of credit constraints, namely, entrepreneurial households are considered as credit constrained if they are constrained for the purpose of production as well as housing or vehicles. As shown in column 1 to 2 , the altered definition of credit constraints does not affect our main conclusion.

\subsubsection{Estimation with a Narrower Definition of Entrepreneurial Households}

Some left-behind elderly work in agriculture, but only produce for selfsufficient. They would not sell the production to make profit when the young members migrate to urban areas, which is a common situation in rural China. Our concern is that estimation bias may arise if we consider these rural households as entrepreneurial households as well. To address this possible estimation bias, we use a narrower definition of entrepreneurial households, namely, those who only work in agriculture and do not trade with others to make profit are excluded from our sample entrepreneurial households. Thus, we re-estimate the model by excluding these self-sufficient rural households (about $2 \%$ of our total sample size) in the estimation. The estimation results are presented throughout column 3 to 4 . We can see that the narrower definition of entrepreneurial households do not change our main conclusion.

\subsubsection{Estimation with Transformed Loans}

To check whether the estimated results would be sensitive to transformed loans, we use the natural logarithm of loans as explanatory variable instead. The estimation results are reported throughout column 5 to 6 . We can see that (the natural logarithm of) loans has a significant and positive effect on both constrained and unconstrained entrepreneurs, but the estimated coefficient on loans is slightly smaller for the unconstrained ones $(0.0822$ versus 0.0741$)$. This still qualitatively supports the earlier finding that the marginal effect of credit on profits is higher for credit-constrained entrepreneurs.

\subsubsection{Estimation with Macroeconomic Factors}

Considering that macroeconomic factors may also affect rural entrepreneurial performance, we further control provincial economic factors such as rural 
economic development, rural financial development, and financial support for agriculture in the model estimation. To reduce reverse causality, we use provincial economic data in 2010. GDP per capita in rural areas is used as a proxy for rural economic development. It is calculated by taking the sum of the added value of agriculture, forestry, animal husbandry, fishery, and rural enterprises, and then divided by rural population. ${ }^{4}$ Rural financial development is calculated by using annual outstanding loans from rural credit cooperatives, ${ }^{5}$ divided by GDP per capita in rural areas. ${ }^{6}$ Financial support for agriculture is denoted by the share of public expenditure on agriculture, forestry, and water affairs in total public expenditure. ${ }^{7}$ The estimation results are reported throughout column 7 to 8 . After controlling provincial macroeconomic factors, our conclusion remains robustness.

\subsection{Heterogeneity Analysis}

The effect of credit constraints on rural households' entrepreneurial performance may vary by the gender, age, and education level of the household head. Therefore, we further investigate the potential heterogeneous effects of credit constraints on households' entrepreneurial performance across subsamples.

Panel A-C in Table S6 presents the estimated results of heterogeneity in liquidity effects across the gender, age, and education level of the household head. First, we find that improving credit access would increase both male and female-headed constrained households' entrepreneurial performance. The magnitude of the estimated effect is much larger for female-headed subsample than male-headed subsample, which implies that female entrepreneurs are more likely constrained in the credit market; thus, rural financial institutions should also target female entrepreneurs. Second, for younger subsample, credit access has a significant and positive effect on both constrained and unconstrained entrepreneurial households' profits. However, the magnitude of the estimated effect is much larger for constrained ones than unconstrained ones. For elder subsample, credit access has a significantly negative effect on unconstrained entrepreneurial households' profits, while the effect on constrained entrepreneurial households' profits is not significant, suggesting that credit constraints are not the main obstacles to entrepreneurship for elder ones. Third, credit access only has a significant and positive effect on constrained entrepreneurial households' profits in higher education subsample, while this effect is not significant in lower education subsample. The results reflect that removing credit constraints is effective in improving profits for households with a higher education level. While for households with lower education level, other than credit services, they may need services on production such as the training of the applications of new techniques, which could lower costs and boost profits. 


\section{Conclusion}

Based on CHFS data for the year 2011, we estimate the effect of credit constraints in the formal sector on the entrepreneurial performance of rural households by using an endogenous switching regression model. We find that, unlike for unconstrained entrepreneurs, the profits of credit-constrained entrepreneurial households are significantly and positively affected by credit access. With an extra RMB 10,000 in credit, constrained entrepreneurial households' average profits would be raised from RMB 10,604 to RMB 10,732 (i.e. by $1.2 \%$ ). Moreover, whether or not entrepreneurial households are credit constrained depends on a number of factors. In particular, we find that households that experienced land expropriations, households with relatively few nonproductive assets, and siblings are more likely to be credit constrained.

Our findings have several clear policy implications. First, our finding that credit constraints in the formal sector adversely affect entrepreneurs' profits suggests that informal finance is not a perfect substitute for formal sector finance in China. The Chinese government has adopted a number of measures to promote formal credit markets since 2007. For instance, microcredit companies, village banks, and rural credit union funds have been encouraged to start operations in rural districts in China. Furthermore, eligible micro-credit companies have been allowed to be transformed into village banks since 2012, which has led to a boom in village banks. Private capital is encouraged to be invested in these new-type rural financial institutions ${ }^{8}$ which may help to construct a more effective and competitive rural financial environment. Our findings show that better access of entrepreneurial households to these new-type formal financial institutions is likely to improve the performance of these households. Second, we find that households that experienced land expropriations are more likely to be creditconstrained, suggesting that on average the compensations were less than sufficient to allowing expropriated households to make optimal decisions on entrepreneurial activities that might compensate for the loss of arable land. Finally, our results show that households with relatively few nonproductive assets are more likely to be credit-constrained and, as a consequence, have lower-performing entrepreneurial activities. This finding points to the need to stimulate savings and investments in different types of assets by rural households that can be used as a source of finance when households are faced with liquidity shortages, given also the limited possibilities of using arable land as a collateral for obtaining loans.

\section{Notes}

1. For details on the CHFS sampling design, see: https://chfs.swufe.edu.cn/. 
2. Since there are no questions in the survey asking whether or not the household received the full amount of the loan it applied for, we restrict quantity constrained households to those who are completely constrained in the formal credit market.

3. In the survey, respondents were asked to report the purpose (production, housing, vehicles) of the loans they obtained in the formal or informal markets. Here we focus on total formal and informal loans for productive uses.

4. Data collected from "China Agricultural Yearbook (2011)".

5. Data collected from "Almanac of China's Finance and Banking (2011)".

6. Data collected from "China Agricultural Yearbook (2011)".

7. Data collected from "China Statistical Yearbook (2011)".

8. According to the China Banking Regulatory Commission, new-type rural financial institutions refer to micro-credit companies, village banks and rural credit union funds. See http://www.cbrc.gov.cn/chinese/home/docDOC_ReadView/2923.html.

\section{Funding}

This work was supported by the National Office for Philosophy and Social Sciences (17\&ZDA037), Ministry of Education of the People's Republic of China (18YJC790177), Social Science Foundation of Jiangsu Province (18EYC008), Jiangsu Provincial Department of Education (2018SJA0245).

\section{References}

Ali, D. A., K. Deininger, and M. Duponchel. 2014. Credit constraints and agricultural productivity: Evidence from rural rwanda. Journal of Development Studies 50 (5):649-65. doi:10.1080/00220388.2014.887687.

Boucher, S. R., C. Guirkinger, and C. Trivelli. 2009. Direct elicitation of credit constraints: Conceptual and practical issues with an application to peruvian agriculture. Economic Development and Cultural Change 57 (4):609-40. doi:10.1086/598763.

Burke, A. E., F. R. FitzRoy, and M. A. Nolan. 2000. When less is more: Distinguishing between entrepreneurial choice and performance. Oxford Bulletin of Economics and Statistics 62 (5):565-87. doi:10.1111/1468-0084.00190.

Cai, D., Q. Song, S. Ma, Y. Dong, and Q. Xu. 2018. The relationship between credit constraints and household entrepreneurship in China. International Review of Economics \& Finance 58:246-58. doi:10.1016/j.iref.2018.03.024.

De Mel, S., D. McKenzie, and C. Woodruff. 2008. Returns to capital in microenterprises: Evidence from a field experiment. The Quarterly Journal of Economics 123 (4):1329-72. doi:10.1162/qjec.2008.123.4.1329.

Evans, D. S., and B. Jovanovic. 1989. An estimated model of entrepreneurial choice under liquidity constraints. The Journal of Political Economy 97 (4):808-27. doi:10.1086/ 261629.

Guirkinger, C., and S. R. Boucher. 2008. Credit constraints and productivity in peruvian agriculture. Agricultural Economics 39 (3):295-308.

Hvide, H. K., and J. Møen. 2007. Liquidity constraints and entrepreneurial performance. Discussion Paper 6495. CEPR.

Li, R., Q. Li, S. Huang, and X. Zhu. 2013. The credit rationing of chinese rural households and its welfare loss: An investigation based on panel data. China Economic Review 26:17-27. doi:10.1016/j.chieco.2013.03.004. 
Lokshin, M., and Z. Sajaia. 2004. Maximum likelihood estimation of endogenous switching regression models. Stata Journal 4:282-89. doi:10.1177/1536867X0400400306.

Ma, S., X. Wu, and L. Gan. 2019. Credit accessibility, institutional deficiency and entrepreneurship in China. China Economic Review 54:160-75. doi:10.1016/j.chieco.2018.10.015.

McKernan, S.-M. 2002. The impact of microcredit programs on self-employment profits: Do noncredit program aspects matter? Review of Economics and Statistics 84 (1):93-115. doi:10.1162/003465302317331946.

Quadrini, V. 2000. Entrepreneurship, saving, and social mobility. Review of Economic Dynamics 3 (1):1-40. doi:10.1006/redy.1999.0077.

Van Praag, M., G. De Wit, and N. Bosma. 2005. Initial capital constraints hinder entrepreneurial venture performance. The Journal of Private Equity 9 (1):36-44. doi:10.3905/ jpe.2005.605369.

Zhang, D., Z. Tong, and Y. Li. 2020b. The role of cash holding towards cleaner production in China's manufacturing sectors: A financial constraint perspective. Journal of Cleaner Production 245. doi: 10.1016/j.jclepro.2019.118875

Zhang, D., L. Zhuge, and R. B. Freeman. 2020a. Firm dynamics of hi-tech start-ups: Does innovation matter? China Economic Review 59:2-17. doi:10.1016/j.chieco.2019.101370. 